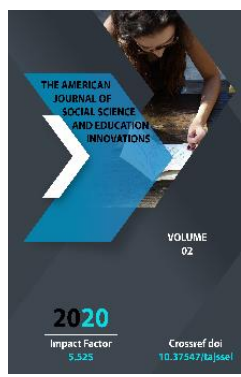

\title{
Features Of The Formation Of Nouns Using Affixes With A Negative Connotation In Modern Chinese
}

\author{
Khilola Sadulla Kizi Yusupova \\ Department Of “Chinese Philology", Faculty Of "Chinese Studies", Tashkent State University \\ Of Oriental Studies, Uzbekistan
}

Copyright: Original content from this work may be used under the terms of the creative commons attributes 4.0 licence.

\section{ABSTRACT}

This article is devoted to the study of the peculiarities of the formation of nouns using affixes with a negative connotation in modern Chinese. The relevance of the study is due to the fact that this phenomenon is widespread in the word formation of the modern Chinese language and ranks second in the productivity of the formation of both new lexical units and various forms of the word. The leading approach to the study of this problem is component analysis, as well as the modeling of structures, with the help of which the corresponding noun words are formed, allowing comprehensively considering this phenomenon within the framework of the affixation of the modern Chinese language.

\section{KEYWORDS}

Affixation, suffix, morpheme, vocabulary, attributive model, subject-predicative model, verb-object model.

\section{INTRODUCTION}

In the modern Chinese language, the methods of word formation have been studied to varying degrees by both domestic and foreign linguists. For example: A. Reformatsky [1, p.
542.], Gao Yaochi [2, p. 220], Zhang Jing [3, p. 220], Sun Changxu [4, p. 493], WangChao Yuan [5, p. 64]. E. Kubryakova [6, p. 78], Lu Zhiwei [7, p. 160], Zhen Xuelyan [8, p. 320], Zhang 
Shoukang [9, p. 96], S. Nosirova [10, p. 150 ], S. Khashimov [11, p. 150] and many others. So, one of the ways of word formation is affixation. This method is widely used in the formation of various words related to different parts of speech of the modern Chinese language. This article is devoted to the study of affixes, with the help of which animate nouns are formed in modern Chinese. In modern Chinese, semi-affixes that form words related to the noun part of speech make up a significant part of the affixes. They form noun words with the meaning of a person's professions, names of objects, their qualitative shades, etc. Such semi-affixes include the following morphemes as examples: 员 “yuan”, 师 “shi”, 生 “sheng”, 汉 “han”, 士 “shi”, 夫 “fu”, 客 “ke”, 手 “shou”, 丁 “ding”, 鬼 “gui”, 虫 “chong”, 蛋 “dan”, 派 “pai”, 份子 “fenzi”, 物 “wu”, 品 “pin”, 素 “su”, 体 “ti”, 力 “ij”, 处 “chu”, 心 “xin”, 意 “yi”, 性 “xing”, 切 “que”, 当 “dang”, 学 “xue”, 论 “lun”, 主义 “zhuyi”, 化 “hua”" and etc.

Consider one group of suffixes through which animate nouns are formed.

\section{DISCUSSION}

The affix 鬼 “gui” forms noun words with evaluative-expressive coloring. These nouns express people with negative qualities. Zhen Xuelyan marks this morpheme as (比喻性的 词 尾 “biyuxingde ciwei”) “suffix with evaluative coloration". The root of this affix is root morpheme 鬼 “gui” (“damn”). Words with this affix 鬼 “gui” appeared in colloquial speech, but, despite this, are widely used in the literary language. For example: 醉鬼 “zuigui”, 酒鬼 “jiugui” “drunkard”, 胆小鬼 “danxiaogui” “coward”, \#鬼 “chougui” “freak”, 穷鬼 “qionggui” “beggar”, 油滑鬼 “youhuagui” “cunning”, 烟鬼 “yangui” "drug addict". Nouns are formed using this suffix based on the following models: 1) [noun +鬼“gui”= noun]: 酒鬼 “jiugui” “drunkard”, 2) [verb +鬼“gui”= noun]：讨厌鬼“taoyangui” “cheat”, 3) [adjective +鬼“gui”= noun]：穷鬼 “qionggui" "beggar". Thus, we can safely say that the words formed by this suffix have a negative meaning, for example: 酒鬼 “jiugui” “drunkard” (酒 “jiu” “alcoholic drink”, “wine”) , 烟鬼 “yangui” “drug addict” (烟 “yan” “cigarette”)，赌鬼 “dugui” “people, keen on gambling”( 赌 “du” “gambling”).

\section{THE MAIN FINDINGS AND RESULTS}

With the help of the affixes 虫 “chong” and 蛋 "dan" a subjective (negative) meaning is added to the lexical unit. These affixes are semi-suffixes and are genetically related to the morphemes 虫 “chong” (“insect”, “worm”) and 蛋 “dan” (“egg”). Nouns are formed using these semi-suffixes only using the following construction: ["adjective" + 虫 “chong” / 蛋 "dan" = "noun"]. In this case, these affixes, being part of complex words, partially lose their original meaning, for example: 糊涂虫 “hutuchong”, 糊涂蛋 “hutudan” “idiot”, 笨蛋 “bendan” “fool”, 浑蛋 “hundan” “stupid”,穷 光蛋 “qiongguangdan” “beggar”.

Morpheme 贼 “zei” means “thief”, this morpheme as well as 霸 “ba”, 棍 “gun” forms words with negative meaning. The words formed by this morpheme are formed according to the model [verb + 贼 “zei" = noun], for example：卖国贼 “maiguozei” "traitor".

Morpheme 霸 “ba” “tyrant”, “despot”, "hegemon" forms words with a negative connotation, lexical units are constructed according to two models: 1) [noun + 霸 "ba" = noun], for example: 路霸 “luba” “road”, 2) [adjective + 霸“ ba "= adjective], for example: 恶霸“ eba "“ bully”. 
The morpheme 㿋 “pi” means "bully" and forms words according to two patterns: 1) [noun + 㾂 “pi” = noun], for example: 文㾙 “wenpi” “rogue”, 街㾂 “jiepi” “bully”.

The morpheme 犯 “fan" "to spoil” as a suffix also forms nouns : 1) [monosyllabic noun + 犯 “fan" = noun], for example: 首犯 “shoufan” "leader against the law", 2) AB (noun formed according to subjective -predicative model) + 犯 “fan” = noun], for example: 政治犯 "zhengzhifan" "anti-politics", 3) [AB (verb object model noun) + 犯 “fan” = noun] eg: 杀 人犯 “sharenfan” “murderer” , 4) [preposition + 犯 “fan" = noun], for example: 从犯 “congfan" “accomplice”, "pander”, 5) [monosyllabic verb + 犯 “fan" = noun], for example: 罪犯 “zuifan” “person who broke the law".

The morpheme 棍 “gun” means "stick" and forms new words related to the part of speech noun according to two constructions, the words formed with this morpheme have a negative connotation: 1) [noun + 棍 “gun" = noun], for example: 土棍“Tugun” “bully”, 2) [adjective + 棍 “gun” = noun], for example: 恶 棍 “egun” “scoundrel”.

The morpheme 观 “guan" means "point of view", when used as a suffix, this morpheme retains its lexical meaning, for example: 乐观 “leguan” “optimistic point of view”, 悲观 "beiguan" "pessimistic point of view”. Words with the 观 “guan" suffix are formed according to the construction [noun + 观 “guan”], [verb + 观 “guan”], [adjective + 观 “guan”].

The morpheme 症 “zheng" means "disease", when used as a suffix, this morpheme retains its lexical meaning, for example : 病症 “bingzheng” “disease”，稽征 “jizheng” “audit of the disease”，杂症 “zazheng” “various disease". Words with the suffix 症 "zheng" are formed according to the construction [noun + 症 “zheng”], [verb + 症 "zheng"].

The morpheme 炎 "yan" also means "disease", when used as a suffix, this morpheme retains its lexical meaning, for example : 肺炎 “feiyan" "pneumonia”， 耳炎 “qiyan" “otitis media". Words with the 炎 "yan" suffix are formed according to the construction [noun + 炎 “yan”], [verb + 炎 “yan”].

Morpheme 点 “dian” means "hour", "point” and also retains its meaning as a suffix, for example: 缺点 “quedian” “lack” [1, p. 54]. Words with the 点 "dian" suffix are formed according to the construction [adjective + 点 “dian”], [verb + 点 “dian”].

The affix 手 "shou" forms the names of various professions, and also forms words for people who are knowledgeable and specialists in the relevant field. The root of this morpheme is the morpheme 手 "shou" ("hand"). With the help of this affix, words with a negative meaning are also formed, for example: 凶手 "shashou" "killer", "flayer".

The affix 意 “yi” forms words related to nouns. With the help of this affix, words are also formed that denote features of a person's character and behavior. With the help of this affix, words with a negative meaning are also formed. This affix is genetically related to the morpheme 意 “yi” (“thought”, “desire”), for example: 大意 “dayi” “inattention”, 醋意 “cuyi” “jealousy”, 妒意 “huyi” “envy”. Sometimes, with the help of this morpheme, nouns denoting the physiological and psychological states of a person are also formed, for example: 倦意 “juanyi” "fatigue”, 羞 意 “xiyi” “shyness”. Words containing the suffix 意 “yi" are formed according to the following three constructions: ["adjective" + 意 “yi” = “noun"] and ["verb" + 意 “yi” = “noun”] wa [“ noun ”+ 意“ yi "=“ noun ”]. As an example, consider the following sentences: 
这种信息在有些人的心头便弓 / 起了一

种敌 意. [2, p. 55]

"This news has raised doubts among some". ( 敌意 “guyi” “doubt”).

妒意当然是无所用之了[3, p. 56]

“There is no reason for envy”. (妒 意 “duyi” "envy").

In modern Chinese, there is also a group of words that are on the periphery of transformation into derivational morphemes. This group includes the second elements of four-syllable constructions formed according to the "noun + noun" model. For example: 主 义 “zhuyi” “theory”, "basic idea”, 行为 “xingwei” "action", “act”, 运 动 “yundong” “sport”, “kind of sport”, 阶 级 “jieji” “class ”(As a group of people), 制度“ zhidu ”“ system "and others.

The lexical unit 行为 “xingwei" in a word is used in an abbreviated form 行 “xing". Words formed by the morpheme 行 “xing” express a person's action or the negative meaning of a corresponding action. For example: 粗鲁行为 “culu xingwei” “cruelty”, 逃跑行为“taopao xingwei” “desertion”, 无 礼行为 “wuli xingwei" “arrogance". 行 为 “xingwei” in modern Chinese is a productive grammatical element.

The morpheme 分子 “fenzi” is translated as "molecule", as a suffix this morpheme loses its lexical meaning. Words formed through this suffix denote specific qualities or character of people. For example: 危险分子 “weixianfenzi” “dangerous person", 动摇 分子 “dongyaofenzi" “two-faced" [4, p. 54]. Words with this suffix are constructed according to the following patterns: [noun + 分子 “fenzi”], [adjective + 分子 “fenzi”], [verb + 分子 "fenzi"].

\section{CONCLUSION}

Based on the above, we can conclude that:

1) As one of the ways of word formation, affixation, when constructing new lexical units, forms various lexical units with various structural and semantic features.

2) According to the functional classification, affixes are divided into word-building and form-building. This division of affixes into these groups is based on functionalsemantic, structural and distributive criteria.

3) In modern Chinese, affix word formation in terms of productivity takes second place after word formation.

\section{REFERENCES}

1. 王珏。现代汉语名词研究。- 上海, 2000。一页54。

2. 王珏。现代汉语名词研究。- 上海, 2000。-页55。

3. 王珏。现代汉语名词研究。一上海, 2000 。 - 页 56 。

4. 王珏。现代汉语名词研究。一上海, 2000。 - 页54。

5. Gao Yaoqi. Xiandai hanyu yufa. Henan, 1982. - 266 ye.

6. Zhang Jin. Ju, cizu, juzi. - Haerbing, 1984. -220 ye.

7. Xun Chanxu. Hanyu cihui. - Changchun, 1956. -493 ye.

8. Lu Zhiwei. Hanyude goucifa. - Beijing, 1957. - 160 ye.

9. Ren Xueliang . Hanyu zaocifa. - Beijing, 1980. - 320 ye. 
10. Zhang Shoukan Goucifa he gouxingfa. Hubei, 1981. - 96 ye.

11. Носирова С. Хитой тилининг ижтимоийсиёсий ва дипломатик терминологияси. - Т.: Янги аср авлоди, 2011. - 1506. (Nosirova C. (2011) Socio-political and diplomatic terminology of the Chinese language. - Tashkent: Yangi asr avlodi. - p. 150)

12. Хашимова С. Носирова С. Хитой тили грамматикаси. - Т.: Jahon Press, 2012. 150 6. (Xashimova S. Nosirova S. (2012) Chinese grammar. - Tashkent.: Jahon Press. - p. 150)

13. Хашимова С. Хозирги хитой тилида редупликация. аффиксация ва конверсия. - Т., 2020. - 328 б. (Xashimova S. (2020) Reproduction in modern Chinese. affixation and conversion. - Tashkent. - p. 328)

14. 语言学名词解释.- 北京: 商务印书馆, 1960. - 1205 页。

15. Zhou Zumo. Hanyu cihui jianghua. Beijing, 1962. - 175 ye.

16. 李稿. 现代汉语动词研究. - 北京, 2004年. -187 ye.

17. 王珏。现代汉语名词研究。 - 上海, 2000。-256页 